\title{
Pregnancy in a woman with premature ovarian failure
}

\author{
Nicholas Finer ${ }^{1}$, Ignac Fogelman ${ }^{2}$ and Gianfranco Bottazzo ${ }^{3}$
}

\author{
Departments of ${ }^{1}$ Medicine and ${ }^{2}$ Nuclear Medicine, Guy's Hospital and Medical School, St. Thomas Street, \\ London Bridge SE1 9RT and ${ }^{3}$ Department of Immunology, Middlesex Hospital Medical School, 40-50 \\ Tottenham Street, London WIP 9PG, UK.
}

\begin{abstract}
Summary: We report the case of a 32 year old woman with premature ovarian failure associated with ovarian autoantibodies, autoimmune Addison's disease and primary hypothyroidism who became pregnant following the treatment of her thyroid and adrenal deficiencies.
\end{abstract}

\section{Introduction}

When ovarian failure occurs with a premature menopause it is usually associated with elevated gonadotrophin levels and the absence of follicles in the ovary. However, a syndrome of ovarian failure with persisting ovarian follicles is recognized and has been variously termed the 'savage', 'resistant' or 'insensitive ovary syndrome' (Tulandi \& Kinch, 1981). The mechanism for this condition is not known but on rare occasions ovarian function may recover and pregnancies have been reported (Tulandi \& Kinch, 1981). Premature gonadal failure is, however, relatively common in Addison's disease - in one series it was present in over $25 \%$ of women (Irvine \& Barnes, 1972). It is usually ovarian in origin with hypergonadotrophism and low oestrogen levels. Laparoscopy may show lymphocytic infiltration of the ovaries, or the presence of streak ovaries in cases of primary amenorrhoea (Irvine \& Barnes, 1972). Gonadal failure is particularly common in those subjects with 'idiopathic' disease and may precede the onset of adrenal insufficiency by many years (Turkington \& Lebovitz, 1967). Ovarian (steroid cell) autoantibodies are IgG antibodies that react with steroid producing cells in the gonads. They may be present in up to $50 \%$ of patients with Addison's disease without gonadal failure, and may also occur when adrenal autoantibodies are not present (Sotsiou et al., 1980). Amenorrhoea or an early menopause was always present in subjects with autoantibodies to both adrenal cortex and ovarian theca interna cells (Irvine \& Barnes, 1972; Sotsiou et al., 1980). This case report describes a patient with Addison's disease and premature ovarian failure associated with these autoantibodies who became pregnant.

Correspondence: I. Fogelman, M.D., M.R.C.P.

Accepted: 25 June 1985

\section{Case report}

A 32 year old woman presented with a classical history of Addison's disease. She had felt increasingly tired and weak over a period of six months, with dizziness on standing and then nausea and vomiting. She gave a history of 7 years' primary infertility, which had been investigated elsewhere and attributed to an early menopause. For 18 months she had had complete amenorrhoea.

On examination she was pigmented, thin and had postural hypotension. Investigations confirmed Addison's disease with $09.00 \mathrm{~h}$ plasma cortisol of $86 \mathrm{nmol} / 1$ and no cortisol response to Synacthen. Adrenocorticotrophin (ACTH) levels were elevated at $>500 \mathrm{pg} / \mathrm{ml}$ (normal $<71 \mathrm{pg} / \mathrm{ml}$ ). Her thyroid was not palpable. Serum thyroxine $\left(\mathrm{T}_{4}\right)$ was $14 \mathrm{nmol} / 1$ (normal range $65-155 \mathrm{nmol} / \mathrm{l}$ ) and serum thyrotrophin (TSH) elevated at $>25 \mathrm{mU} / \mathrm{l}$, thus confirming the diagnosis of primary myxoedema. Gonadotrophins were compatible with ovarian failure; follicle stimulating hormone $(\mathrm{FSH})>20 \mathrm{U} / 1$ (normal $<5 \mathrm{U} / 1$ and luteinizing hormone $(\mathrm{LH})<50 \mathrm{U} / 1$ (normal $16 \mathrm{U} /$ 1; plasma oestradiol was undetectable $(<40 \mathrm{nmol} / \mathrm{l})$. Serum prolactin was normal $(327 \mathrm{mU} / \mathrm{l})$ and there was no evidence of hypoparathyroidism. Antibody studies showed adrenal (titre 1/320) and ovarian-steroid cell $(1 / 320)$ autoantibodies, detected by immunofluorescence. Mitochondrial (1/10), stomach gastric parietal cell $(1 / 640)$, smooth muscle antibodies $(1 / 20)$ and thyroid microsomal haemagglutinating antibodies (1/ $160)$ were also detected. Thyroglobulin, pituitary and pancreatic islet cell antibodies were negative.

The patient was commenced on hydrocortisone $30 \mathrm{mg} / \mathrm{d}$, fludrocortisone $50 \mu \mathrm{g} / \mathrm{d}$ and L-thyroxine $100 \mu \mathrm{g} / \mathrm{d}$. Six weeks after starting this treatment she menstruated and gonadotrophins were found to have 
fallen: LH 8.6 U/1 and FSH 9.2 U/1. Plasma oestradiol was $237 \mathrm{pmol} / 1$ (normal range for early follicular phase). A cortisol profile showed adequate glucocorticoid replacement, and $\mathrm{T}_{4}$ was in the normal range. Three months after starting replacement therapy she complained of a recurrence of her original symptoms investigations showed her to be pregnant. The date of conception was estimated from ultrasound to have been approximately 6 weeks after the commencement of therapy. Ovarian autoantibodies were remeasured at this time and persisted in unaltered titres. Her symptoms responded to an increase in hydrocortisone and fludrocortisone.

\section{Comment}

Our patient presented with Addison's disease, hypothyroidism and ovarian failure. Evidence for the latter was her amenorrhoea, undetectable oestradiol and the presence of grossly elevated gonadotrophins. When infertility or amenorrhoea is associated with nonspecific illness or stress the usual finding is hypogonadotrophic hypogonadism. Prolactin levels were not elevated despite the hypothyroidism, and cannot be implicated as causing the amenorrhoea or infertility. The fall in gonadotrophins associated with a return of menstruation after 6 weeks' adrenal and thyroid

\section{References}

DONIACH, D. BOTTAZZO, G.F. \& RUSSELL, R.C.G.(1979). Goitrous autoimmune thyroiditis (Hashimoto's disease). Clinics in Endocrinology and Metabolism, 8,63.

IRVINE, W.J. \& BARNES, E.W. (1972). Adrenocortical insufficiency. Clinics in Endocrinology and Metabolism, 1, 549. MCNATTY, K.P., SHORT, R.V. BARNES, E.W. \& IRVINE, W.J. (1975). The cytotoxic effect of serum from patients with Addison's disease and autoimmune ovarian failure on human granulosa cells in culture. Clinical and Experimental Immunology, 22, 378. hormone replacement, and the subsequent pregnancy all indicate that she had reversible 'ovarian failure'.

All the previously reported cases of ovarian failure $c$ in association with ovarian autoantibodies were irreversible. Ovarian autoantibodies have been shown to be cytotoxic to ovarian cells in vitro (McNatty et al, 1975) but whether they cause ovarian failure in vivo may depend upon other factors such as the individual's cell-mediated immune response. While it is $\stackrel{\mathbb{D}}{\triangle}$ recognized that autoimmune disorders may follow a fluctuating course (Doniach et al., 1979) ovarian $\vec{\circ}$ antibody titres were constant in this case. In the 'resistant ovary syndrome' pregnancy is rare and $\vec{\omega}$ reported cases have usually occurred after oestrogen or gonadotrophin therapy. Thus the explanation for the recovery of ovarian function in our patient follow-

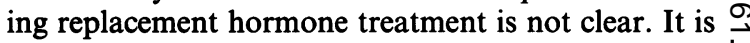
unlikely that physiological doses of steroids would have any immunosuppressant effect.

This case is exceptional but it provides a further $\vec{\circ}$ reminder that ovulation may still occur after a oै

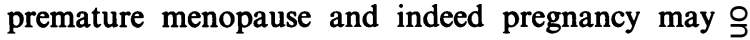
ensue.

\section{Addendum}

We are pleased to report that this patient subsequently delivered a healthy boy.

SOTSIOU, F., BOTTAZZO, G.F. \& DONIACH, D. (1980). Immunofluorescence studies on autoantibodies to steroid- $\triangle$ producing cells, and to germline cells in endocrine disease $\vec{F}$ and infertility. Clinical and Experimental Immunology, 39, 97.

TULANDI, T. \& KINCH, R.A.H. (1981). Premature ovarian failure. Obstetric and Gynaecological Survey, 36, 521.

TURKINGTON, R.W. \& LEBOVITZ, H.E. (1967). Extraadrenal endocrine deficiencies in Addison's disease. American Journal of Medicine, 43, 499. 